\title{
Currarino syndrome
}

INSERM

\section{Source}

INSERM. (1999). Orphanet: an online rare disease and orphan drug data base. Currarino syndrome. ORPHA:1552

Currarino syndrome (CS) is a rare congenital disease characterized by the triad of anorectal malformations (ARMs) (usually anal stenosis), presacral mass (commonly anterior sacral mening ocele (ASM) or teratoma) and sacral anomalies (i.e. total or partial agenesis of the sacrum and coccyx or deformity of the sacral vertebrae). 